Functional

Ecology 2002

16, $27-39$

\title{
Ecosystem respiration in two Mediterranean evergreen Holm Oak forests: drought effects and decomposition dynamics
}

\author{
M. REICHSTEIN*†, J. D. TENHUNEN*, O. ROUPSARD + J.-M. OURCIVAL $\$$, \\ S. RAMBAL $\ddagger$ S. DORE $\S$ and R. VALENTINI§ \\ *Department of Plant Ecology, University of Bayreuth, D-95440 Bayreuth, Germany, $\$ D R E A M$ Unit, Centre \\ d'Ecologie Fonctionelle et Evolutive, CNRS (1919) route de Mende, Montpellier, France, and §Department of Forest \\ Science and Environment, University of Tuscia, 01100 Viterbo, Italy
}

\section{Summary}

1. We present ecosystem respiration data from two Mediterranean forest sites in central Italy (Castelporziano) and southern France (Puéchabon) in order to analyse the role of soil drought and decomposition dynamics using different models.

2. Ecosystem respiration was derived from continuous eddy covariance measurements. The entire data set was separated into 5-day periods. For each period a function depending on three parameters was fitted to the scatter of eddy $\mathrm{CO}_{2}$ flux versus photosynthetic photon flux density. The $y$ intercept of each curve was taken as an estimate of the average night-time ecosystem respiration during the period. The ecosystem respiration was analysed with different regression models as a function of soil water content and temperature.

3. Ecosystem respiration ranged from 1 to $7 \mu \mathrm{mol} \mathrm{m} \mathrm{m}^{-2} \mathrm{~s}^{-1}$ and showed a clear seasonality, with low rates during drought periods and in winter. The regression model analysis revealed that in drier soil, ecosystem respiration was more sensitive to soil moisture than is expressed by the often used hyperbolic model.

4. In contradiction to a simple multiplicative model, the $Q_{10}$ of ecosystem respiration was not independent of moisture, but increased from nearly 1.0 at low moisture to above $2 \cdot 0$ at field capacity. Several explanations are discussed.

5. Of the variance in ecosystem respiration, $70-80 \%$ was explained with a model where $Q_{10}$ of ecosystem respiration is a function of soil water content.

6. For the Puéchabon site, a soil carbon-balance model predicted only small changes in litter pool size (max. 7\%), which caused only minor changes in soil microbial respiration $\left(0 \cdot 1 \mu \mathrm{mol} \mathrm{m}{ }^{-2} \mathrm{~s}^{-1}\right)$. In contrast, the contribution of microbial regrowth dynamics to ecosystem respiration is estimated to be substantial $\left(\approx 1 \cdot 6 \mu \mathrm{mol} \mathrm{m}^{-2} \mathrm{~s}^{-1}\right)$. The model predicted that soil microbial respiration probably provides the largest contribution to ecosystem respiration $(\approx 50 \%)$. The importance of below-ground processes for ecosystem $\mathrm{C}$ balances is thus emphasized.

Key-words: Carbon cycle, drought effects, eddy covariance, modelling, temperature effects, $Q_{10}$ value

Functional Ecology (2002) 16, 27-39

\section{Introduction}

To predict long-term trends in carbon sequestration by ecosystems, it is necessary to understand the responses of ecosystem respiration - defined as the sum of soil microbial, root, leaf and stem respiration - to environmental factors (Johnson et al. 1996; Jones et al. 2000; Valentini et al. 2000; Vourlitis \& Oechel 1999).

$\uparrow$ Author to whom correspondence should be addressed. E-mail: markus.reichstein@uni-bayreuth.de
A consensus exists with respect to the importance of temperature and water availability in determining ecosystem $\mathrm{CO}_{2}$ emissions. Several reviews have examined the analysis and description of temperature induced increases in soil respiration (Kätterer et al. 1998; Kirschbaum 1995; Lloyd \& Taylor 1994). Less consistent results have been recorded with respect to the influence of soil moisture on respiration, so that different functions describing the dependence have been applied: linear (Epron et al. 1999; Norman et al. 1992); exponential (Davidson et al. 1998; Fang \& Moncrieff 
M. Reichstein et al.
1999; Keith et al. 1997); and hyperbolic (Bunnell et al. 1977; Carlyle \& BaThan 1988; Hanson et al. 1993; Schlentner \& van Cleve 1985). When describing temperature and moisture effects on soil or ecosystem respiration simultaneously, for example in models of global change, it has been assumed that the effects of individual factors may be multiplicative (Bunnell et al. 1977; Fang \& Moncrieff 1999; Hanson et al. 1993). However, this assumption is not well tested and might lead to an overestimation of the respiration response to warming under dry soil conditions (Borken et al. 1999).

Information on the processes controlling net $\mathrm{C}$ gain have often been obtained in extreme habitats, e.g. shaded, hot or cold. The Mediterranean environment is special in that prolonged drought re-occurs annually in a relatively predictable, simple manner (long-term slow drying of the system followed by re-wetting). Thus Mediterranean sites are ideal to examine temporal changes in ecosystem $\mathrm{C}$ balance $\left(\mathrm{CO}_{2}\right.$ fixation, leaf and root phenology, litter and microbial dynamics) in response to soil water availability and temperature (Bottner et al. 1995; di Castri 1981; Rovira \& Vallejo 1997).

While several studies of soil respiration in Mediterranean regions have been conducted in the laboratory (Leirós et al. 1999) and with small chambers in the field (Casals et al. 2000; Merzouki 1986; Pinol et al. 1995), eddy covariance non-intrusively estimates C fluxes under field conditions and at the stand level (Baldocchi et al. 1996). Here we report hourly net ecosystem $\mathrm{CO}_{2}$ exchange measured using eddy covariance in two Mediterranean Quercus ilex L. forests. We attempt to estimate the seasonal course of ecosystem respiration. Our major objective was to evaluate cur- rent model assumptions describing soil respiration as a function of soil temperature and moisture. Further, by using a $\mathrm{C}$ balance model, the contribution of soil microbial respiration to total ecosystem respiration was estimated. How variation in soil litter pools may contribute to variability in overall ecosystem $\mathrm{CO}_{2}$ losses was also tested.

\section{Materials and methods}

\section{SITE DESCRIPTION}

An overview over the site characteristics is given in Table 1. Although climatically quite similar, the two sites differ substantially with respect to water availability due to pedological conditions. Owing to the low maximum soil water availability $(150 \mathrm{~mm})$ at Puéchabon/France, this site is more xeric than the Castelporziano/Italy site, where roots have access to groundwater (Valentini et al. 1992). These conditions are the main reason for the weaker canopy development at Puéchabon (Table 1). See Manes et al. (1997); Merzouki (1986); Joffre et al. (1996) for a more extensive description of the site.

\section{DATA COLLECTION AND TREATMENT}

Net ecosystem $\mathrm{CO}_{2}$ exchange was measured continuously by eddy covariance (Baldocchi et al. 1996). The instruments were a 3D sonic anemometer (Solent, Gill Instruments Ltd, Lymington, UK) which measures the wind vector and air temperature, and a closed-path infrared gas analyser sampling with $10 \mathrm{~Hz}$ (IRGA; LI6262, Li-Cor Inc., Lincoln, NK, USA). The eddy

Table 1. Characteristics and data collection at the study sites Puéchabon and Castelporziano

\begin{tabular}{|c|c|c|}
\hline & Puéchabon & Castelporziano \\
\hline \multicolumn{3}{|l|}{ Characteristics } \\
\hline Location and terrain & $\begin{array}{l}\text { France, flat plateau } \\
\left(43 \cdot 75^{\circ} \mathrm{N}, 3 \cdot 6^{\circ} \mathrm{W}, 250 \mathrm{~m} \text { a.s.l. }\right)\end{array}$ & $\begin{array}{l}\text { Italy, flat basin } \\
\left(41 \cdot 7^{\circ} \mathrm{N}, 12 \cdot 3^{\circ} \mathrm{E}, 7 \mathrm{~m} \text { a.s.l. }\right)\end{array}$ \\
\hline Annual mean temperature $\left({ }^{\circ} \mathrm{C}\right)$ & $13 \cdot 4$ & $15 \cdot 5$ \\
\hline Annual precipitation $(\mathrm{mm})$ & 812 & 740 \\
\hline Canopy species, cover (\%) & $\begin{array}{l}\text { Quercus ilex L. }(>90) \\
\text { Ouercus pubescens L. }(<10)\end{array}$ & $\begin{array}{l}\text { Quercus ilex L. }(>90) \\
\text { Ouercus suber L. }(<10)\end{array}$ \\
\hline Leaf area index $\left(\mathrm{m}^{2} \mathrm{~m}^{-2}\right)$ & $2 \cdot 9$ & $3 \cdot 5$ \\
\hline Stand height (m) & 6 & 10 \\
\hline Soil texture & $\begin{array}{l}\text { clay loam, }>70 \mathrm{vol} \% \text { coarse } \\
\text { fraction }(>2 \mathrm{~mm})\end{array}$ & sand, $<5$ vol $\%$ coarse fraction \\
\hline $\begin{array}{l}\text { Soil parent material } \\
\text { Management history }\end{array}$ & $\begin{array}{l}\text { Jurrasic limestone } \\
\text { coppice, last cut shortly after } 1945\end{array}$ & $\begin{array}{l}\text { Aeolic sands } \\
\text { unmanaged for centuries }\end{array}$ \\
\hline \multicolumn{3}{|l|}{ Data collection } \\
\hline Flux measurements & $\begin{array}{l}\text { Eddy covariance system at } 13 \mathrm{~m} \text {, sap } \\
\text { flow with Granier-type sensor at } 12 \text { trees }\end{array}$ & $\begin{array}{l}\text { Eddy covariance system at } 15 \mathrm{~m} \text {, sap flow } \\
\text { with Granier-type sensors at three trees }\end{array}$ \\
\hline Soil conditions & $\begin{array}{l}\text { Neutron probe at six locations and } \\
\text { from } 0 \text { to } 450 \mathrm{~cm} \text { depth }\end{array}$ & $\begin{array}{l}\text { TDR at five locations in depths } 0-20, \\
30-50,70-90 \mathrm{~cm} \text {, soil temperature at } 10 \mathrm{~cm} \text {, } \\
\text { three locations }\end{array}$ \\
\hline Meteorological variables & $\begin{array}{l}\text { Above the canopy: air temperature, } \\
\text { global and net radiation and } \mathrm{H}_{2} \mathrm{O} \\
\text { pressure, wind speed: all at } 13 \mathrm{~m}\end{array}$ & $\begin{array}{l}\text { above the canopy: air temperature, global } \\
\text { and net radiation and } \mathrm{H}_{2} \mathrm{O} \text { pressure at } \\
16.5 \mathrm{~m} \text {, wind speed at } 12.5 \mathrm{~m}\end{array}$ \\
\hline
\end{tabular}

(C) 2002 British Ecological Society, Functional Ecology, 16, 27-39 global and net radiation and $\mathrm{H}_{2} \mathrm{O}$

$16.5 \mathrm{~m}$, wind speed at $12.5 \mathrm{~m}$ 
covariance system and data processing were as described by Aubinet et al. (2000) (see Table 1 for further information). The half-hourly data sets of $\mathrm{CO}_{2}$ exchange $(\mathrm{Fc})$ and meteorological conditions were aggregated to hourly data by averaging the two observations per hour. In a preparatory step, night-time $\mathrm{CO}_{2}$ fluxes at air temperatures between 10 and $15^{\circ} \mathrm{C}$ and with apparently high soil moisture were plotted against friction velocity $\left(u^{*}\right)$. At both sites, these fluxes increased with $u^{*}$ at low $u^{*}$, and saturated at higher friction velocities. Based on a fitted function, $F c\left(u^{*}\right)=$ $F c_{\text {max }}\left[1-\exp \left(-k u^{*}\right)\right]$, at least $95 \%$ of the maximal night-time $\mathrm{CO}_{2}$ flux was reached at friction velocities above $0 \cdot 2 \mathrm{~m} \mathrm{~s}^{-1}$ ( $k$ always $>15 \mathrm{~s} \mathrm{~m}^{-1}$ ). All eddy covariance data with $u^{*}<0.2 \mathrm{~m} \mathrm{~s}^{-1}$ were excluded from the analysis, as it is likely that under these conditions storage and advection can reduce gas fluxes through the boundary layer. Similarly, negative night fluxes (i.e. with night $\mathrm{C}$ uptake) were excluded. In total, 2260 values or $47 \%$ of the Puéchabon, and 4432 values or $60 \%$ of the Castelporziano hourly data were excluded.

Ecosystem respiration was estimated from scatterplots of net ecosystem $\mathrm{CO}_{2}$ exchange (NEE) versus photon flux density over the canopy as follows. The time-series data were separated into periods of 5 days starting at January 1. For each period with more than 10 night-time observations, the three-parameter stepwise linear regression model:

$F_{c}=\max \left(-\alpha \cdot P P F D ;-F_{c, s a t}\right)+R_{e c o}$

eqn 1

was fitted to the observed hourly eddy covariance flux data $\left(F_{c, o b s}\right)$ (modified Levenberg-Marquardt algorithm, Visual Numerics Inc., 1993) where PPFD is the photosynthetic photon flux density $\left(\mu \mathrm{mol} \mathrm{m} \mathrm{m}^{-2} \mathrm{~s}^{-1}\right), \alpha$ is the apparent ecosystem quantum-use efficiency ( $\mu \mathrm{mol}$ $\mathrm{C} \mathrm{m}^{-2} \mathrm{~s}^{-1} \mu \mathrm{mol}$ photons $\left.\mathrm{m}^{-2} \mathrm{~s}^{-1}\right), F c_{\text {sat }}$ is the gross $\mathrm{C}$

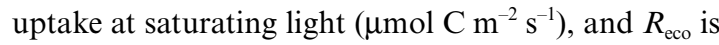
the ecosystem respiration $\left(\mu \mathrm{mol} \mathrm{m} \mathrm{m}^{-2} \mathrm{~s}^{-1}\right)$. In addition, for each 5-day period the averages of air and soil temperature, friction velocity $\left(u^{*}\right)$ and soil water content (SWC) were computed, excluding the same data as in the regression analysis. This procedure resulted in a data set of 5-day means of air and soil temperatures,

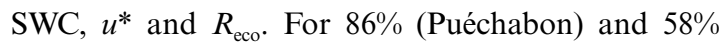
(Castelporziano) of the 5-day periods, respectively, it was possible to provide an estimate of ecosystem respiration according to this procedure.

The SWC was measured bi-weekly at Castelporziano by time domain reflectrometry, and monthly at Puéchabon with neutron probes (cf. Table 1). To interpolate the discontinuous measurements of SWC, a mechanistic model of one-dimensional soil heat and water was utilized (Moldrup et al. 1989; Moldrup et al. 1991, slightly modified as in Reichstein 2001). Driven by hourly observations of global radiation, air temperature, precipitation, vapour pressure deficit and wind speed, this model simulates infiltration and evaporation of water into/from the soil, unsaturated water flow (Richards equation) and extraction of soil water by roots. The total demand of water for transpiration was given by observations of sap flow, which have been performed continuously at both sites. Soil temperature was measured continuously at 10 and $30 \mathrm{~cm}$ depth at the Castelporziano site, and was used to test the soil heat transport model. At the Puéchabon site, soil temperatures were generated only by the model.

\section{ECOSYSTEM RESPIRATION MODELS}

The ecosystem respiration data were analysed with four different models, each with different and partly mutually exclusive assumptions. In all models, soil temperature and soil moisture in the upper soil layer were taken as predictors of ecosystem respiration.

In the first two models, ecosystem respiration was described as being multiplicatively dependent on soil temperature $\left(T_{\text {soil }}\right)$ and soil water content $(S W C)$ :

$R_{\text {eco }}=R_{\text {eco,ref }} \cdot f\left(T_{\text {soil }}\right) \cdot g(\mathrm{SWC})$

eqn 2

where $R_{\text {eco,ref }}$ is the ecosystem respiration at $15^{\circ} \mathrm{C}$ and optimal soil moisture, and $f\left(T_{\text {soil }}\right)$ is the function of Lloyd \& Taylor (1994), normalized to $15^{\circ} \mathrm{C}$ :

$f\left(T_{\text {soil }}\right)=e^{E_{0}\left(\frac{1}{T_{\text {ref }}-T_{0}}-\frac{1}{T_{\text {soil }}-T_{0}}\right)}$

eqn 3

where $T_{\text {ref }}$ and $T_{0}$ are fixed to 15 and $-46^{\circ} \mathrm{C}$, respectively. $E_{0}$, in contrast, was considered to be a free parameter and was fitted to each data set.

Models I and II differ only in the moisture functions used. While in model I the commonly applied saturation function

$g(S W C)=\frac{S W C}{S W C_{1 / 2}+S W C}$

eqn 4

(cf. Bunnell et al. 1977; Hanson et al. 1993) was used, in model II a new function

$$
g(S W C)=\frac{S W C-S W C_{0}}{\left(S W C_{1 / 2}-S W C_{0}\right)+\left(S W C-S W C_{0}\right)}
$$

eqn 5

was used. This is a generalization of model I and allows higher sensitivity of respiration to soil water content during dry periods. The parameters $S W C_{1 / 2}$ and $S W C_{0}$ are the soil water content at which the halfmaximal respiration occurs and the residual soil water content at which respiration is zero, respectively. $S W C$ can be expressed either in absolute terms, as $\mathrm{m}^{3}$ water per $\mathrm{m}^{3}$ total soil volume $(\theta)$, or as relative soil water content $(R S W C)$ as a fraction of field capacity: $R S W C=\theta / \theta_{\text {at field capacity }}$ (field capacity operationally defined as SWC at a matric potential of $330 \mathrm{hPa}$ ).

Models I and II imply that the temperature sensitivity of ecosystem respiration is independent of soil moisture. This assumption is challenged by model approaches III and IV. In model III the data set was 
M. Reichstein et al. split into soil moisture classes (of equal number of observations), and for each class the temperature dependence of ecosystem respiration was described by a simple $Q_{10}$ function:

$$
f\left(T_{\text {soil }}\right)=Q_{10}^{\frac{T_{\text {soil }}-T_{\text {ref }}}{10}}
$$

eqn 6

$\left(T_{\text {ref }}=15^{\circ} \mathrm{C}\right)$. For each moisture class an independent estimate of $Q_{10}$ was obtained. In model IV, the $Q_{10}$ of ecosystem respiration was explicitly linearly dependent on SWC:

$$
\begin{aligned}
f\left(T_{\text {soil }}\right) & =Q_{10}(S W C)^{\frac{T_{\text {soil }}-T_{\text {ref }}}{10}} \text { with } Q_{10}(S W C) \\
& =b_{1}+b_{2} \cdot S W C
\end{aligned}
$$

eqn 7

A positive $b_{2}$ would mean, for example, that temperature sensitivity increases with increasing SWC, in contrast to the assumption that temperature and moisture act multiplicatively on ecosystem respiration. Parameters of all models were estimated from the data sets of 5-daily aggregated ecosystem respiration, soil temperature and soil moisture.

\section{SOIL MICROBIAL RESPIRATION FROM DECOMPOSITION}

We tested if varying litter pools can contribute substantially to the seasonality of respiration. The introductory C balance model (ICBM, Andrén \& Kätterer 1997 ) was used, which assumes two organic $C$ fractions $\left(C_{\mathrm{Y}}\right.$ : young, labile; $\mathrm{C}_{\mathrm{O}}$ : old, stable, $\mathrm{kg} \mathrm{m}^{-2}$ ) decomposed by first-order kinetics [rate constants $k_{1}, k_{2}\left(\right.$ year $\left.^{-1}\right)$ ]. A fraction $h$ of the outflow from $C_{\mathrm{Y}}$ is transformed into $C_{\mathrm{O}}$ ( $h$ represents humification), while the old $\mathrm{C}$ fraction is entirely decomposed to $\mathrm{CO}_{2}$. Litter input $i$ enters the system through the labile $\mathrm{C}$ pool $\left(C_{\mathrm{Y}}\right)$ :

$\frac{d}{d t} C_{Y}(t)=i-r \cdot k_{1} \cdot C_{Y}(t)$ eqn 8

$\frac{d}{d t} C_{\mathrm{o}}(t)=r \cdot h \cdot k_{1} \cdot C_{Y}(t)-r \cdot k_{2} \cdot C_{\mathrm{o}}(t)$ eqn 9

For each time step, the inputs to the ICBM are litter fall $\left(\mathrm{kg} \mathrm{m}^{-2}\right.$ per unit time) and abiotic conditions for decomposition expressed as a scalar $r$. The annual leaflitter fall had been measured at the site for 10 consecutive years (Joffre et al. 1996), while the intra-annual dynamics of leaf-litter fall and the ratio of total litter to leaf litter were assumed to be equal to a nearby site (Lossaint \& Rapp 1978). The scalar $r$ was computed hourly with the functions of model IV (Eqns 5 and 6).

Table 2. Parameterization of the introductory $\mathrm{C}$ balance model (ICBM) for the Puéchabon site

\begin{tabular}{ll}
\hline Parameter & Value \\
\hline Total C stock $C_{\text {tot }}\left(\mathrm{kg} \mathrm{C} \mathrm{m}^{-2}\right)$ & $3 \cdot 25$ \\
Labile C stock $C_{\mathrm{Y}}\left(\mathrm{kg} \mathrm{C} \mathrm{m}^{-2}\right)$ & $0 \cdot 38$ \\
Annual litter input $I\left(\mathrm{~kg} \mathrm{C} \mathrm{m}^{-2}\right.$ year $\left.^{-1}\right)$ & $0 \cdot 384$, see Fig. 1 for time-course \\
Decomposition rate coefficients $k_{1} ; k_{2}\left(\right.$ year $\left.^{-1}\right)$ & $0 \cdot 51 ; 0 \cdot 03$ \\
Humification coefficient $h$ (fraction) & $0 \cdot 20$ \\
\hline
\end{tabular}

For the parameterization of the ICBM, the mass of litter per $\mathrm{m}^{2}$ (interpreted as $C_{\mathrm{Y}}$ ) was measured in the field by sampling the litter from 30 randomly selected circles of $20 \mathrm{~cm}$ diameter at Puéchabon in February 1999. For the estimation of area-based soil C storage, reliable estimates of the soil $\mathrm{C}$ mass per $\mathrm{kg}$ soil were available at Puéchabon. For converting these into areabased values, the bulk density and the stone content of the soil were estimated in the field as in Deutschmann et al. (1994). The rate constant $k_{1}$ and the humification coefficient $h$ were estimated from decomposition experiments of $Q$. ilex litter (leaves and flowers; Gillon et al. 1994) according to Andrén \& Kätterer (1997). The decomposition rate constant $k_{2}$ was parameterized by solving the steady-state equation (eqn 9) for $k_{2}$ (cf. Andrén \& Kätterer 1997; Reichstein et al. 2000), where the subscripts tot and avg mean total and average:

$C_{\text {tot, steady-state }}=\frac{i_{\text {avg }} \cdot\left(1 / k_{1}+h / k_{2}\right)}{r_{\text {avg }}}$ eqn 10

While the steady-state assumption is not proven (potentially introducing errors into the calculation of $k_{2}$ ), small errors in the stable $\mathrm{C}$ decay constant $k_{2}$ do not alter the short-term dynamics. The independent calibration of the soil organic C balance model (ICBM) for the Puéchabon site leads to the parameterization given in Table 2 and the time-course of litter input as shown in Fig. 1. The litter input rate has a distinct maximum in May and a secondary maximum in November.

\section{STATISTICAL ANALYSIS}

Standard errors of non-linear regression parameters were estimated by a bootstrapping algorithm. The original data sets consisting of 5-day aggregated ecosystem respiration, soil temperature and SWC were randomly resampled (with replacement) 500 times, where each resample was made up to the same number of data points as the original data set. The nonlinear regression (nonlinregress in PV-WAVE 6; Visual Numerics Inc 1993) was run for each resample, resulting in 500 parameter estimates per original data set. The standard deviation of these 500 estimates is a good measure of the random error associated with the individual regression parameters (Efron \& Tibshirani 1993).

Model performance was measured with the statistic 'modelling efficiency' (MEF) as recommended by Janssen \& Heuberger (1995), defined as

$$
M E F=1-\frac{\sum_{i=1}^{N}\left(O B S_{i}-S I M_{i}\right)^{2}}{\sum_{i=1}^{N}\left(O B S_{i}-\overline{O B S}\right)^{2}}
$$

where $O B S_{i}$ and $S I M_{i}$ are the corresponding observed and simulated values. In contrast to the coefficient of determination $\left(r^{2}\right)$, the modelling efficiency measures not only the correlation between modelled and observed data, but also their 'coincidence', i.e. the deviation from the $1: 1$ line. 


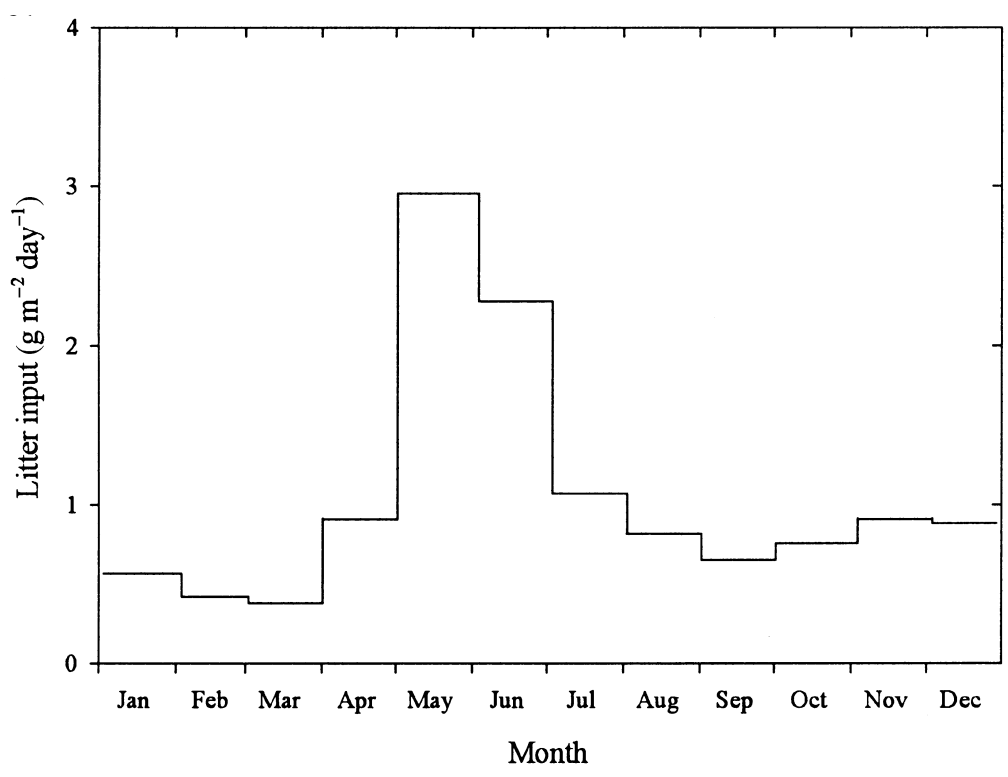

Fig. 1. Estimated annual course of litter $\mathrm{C}$ input (above- and below-ground) for the Puéchabon site. of September). Soil water was severely depleted during this period. Low rainfall during August 1998 recharged only the upper centimetres of the soil (Fig. 2, top), while intensive autumn rainfalls in September rapidly and completely recharged the soil. Soil temperature fluctuated between 20 and $30^{\circ} \mathrm{C}$ during the summer drought and declined to near zero in winter (Fig. 2, bottom). At Castelporziano, the summer drought lasted from the beginning of June until October, leading to a continuous soil water depletion. Similar to Puéchabon, temperatures at Castelporziano were highest in July and August, but were slightly lower than at Puéchabon. At both sites, water dynamics in the upper soil layer were well described by the model (Fig. 2, top). At Puéchabon and Castelporziano, modelling efficiencies were 0.64 and 0.96 , mean absolute errors 0.004 and $0.016 \mathrm{~m}^{3} \mathrm{~m}^{-3}$, respectively. Daily averages of modelled soil temperatures compared well to the observed data at the Castelporziano site (Fig. 2, bottom, MEF $>0 \cdot 9$ ).

\section{ECOSYSTEM RESPIRATION}

The annual course of ecosystem respiration was similar at both sites, exhibiting a clear decrease from early to late summer, and an immediate strong increase after the first rain in autumn (Fig. 3). However, the absolute rates (calculated for $15^{\circ} \mathrm{C}$ and optimum water content) differed between the sites (Table 3), and their ratio approximated the leaf-area ratio between the sites (Table 1).
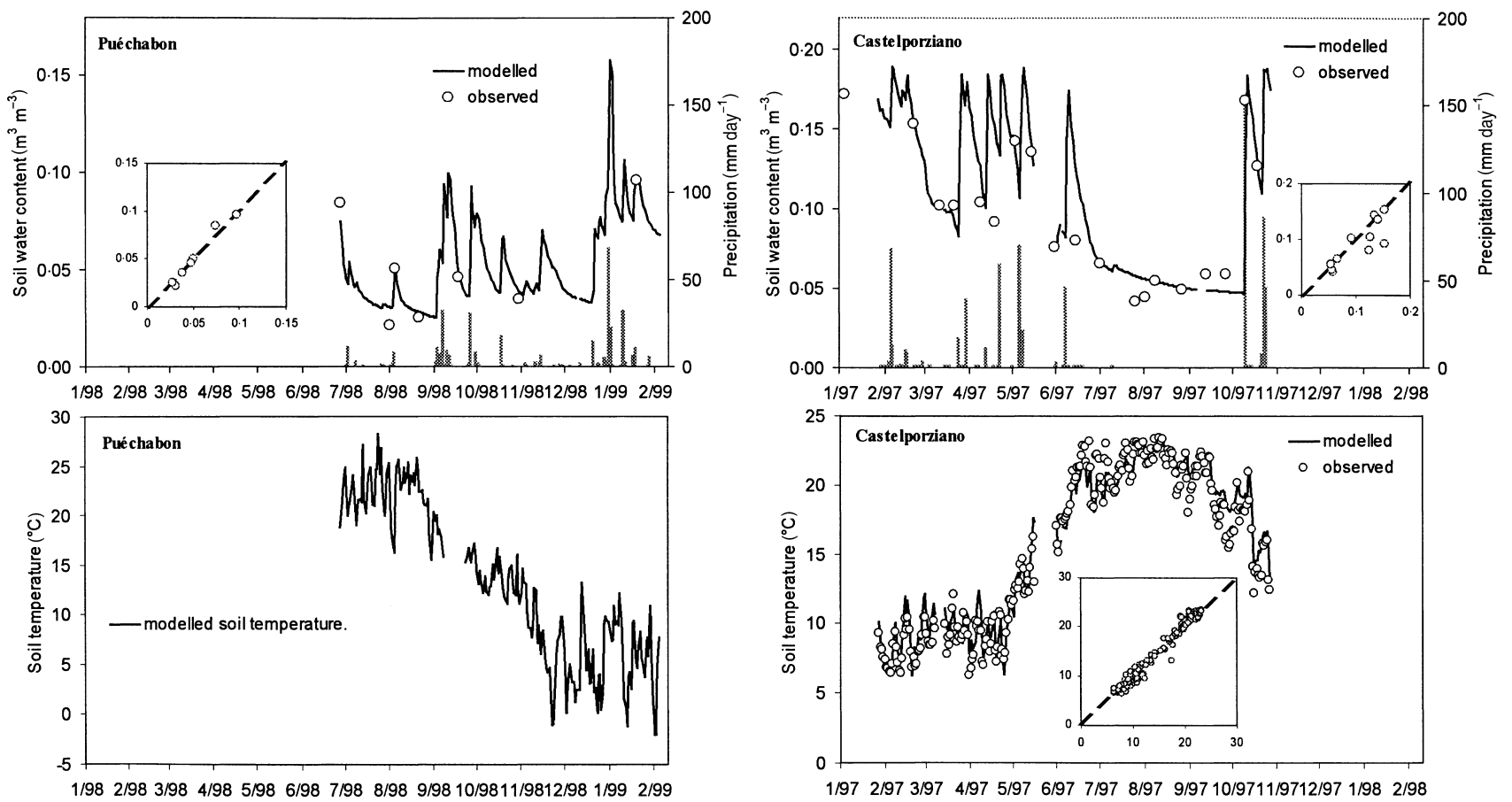

Fig. 2. Upper panels, daily precipitation (grey bars), and modelled and observed upper-layer soil-water dynamics for the Puéchabon and Castelporziano

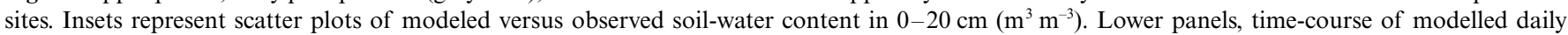
average soil temperatures at $10 \mathrm{~cm}$ depth at the Puéchabon and Castelporziano sites. Also shown are observed soil temperatures, which were only available at the Castelporziano site at $10 \mathrm{~cm}$ depth. The inset shows the observed versus modelled soil temperature at the Castelporziano site. 

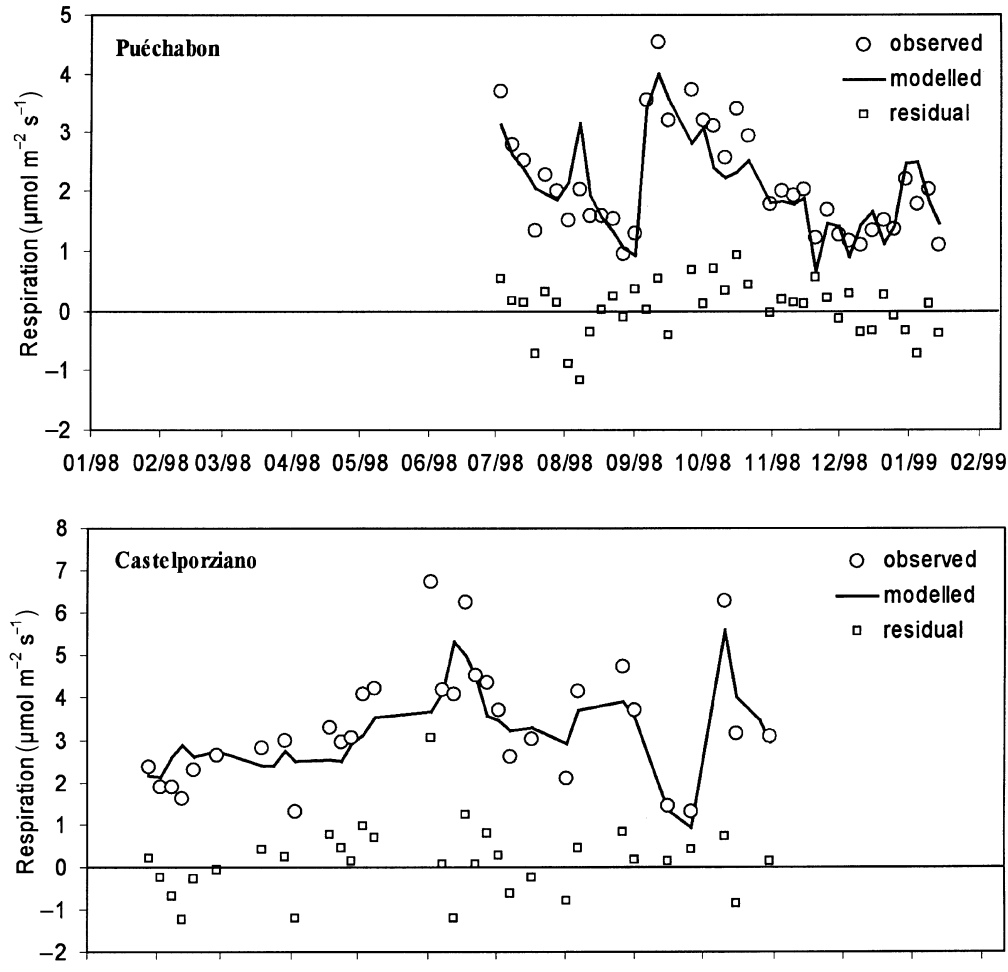

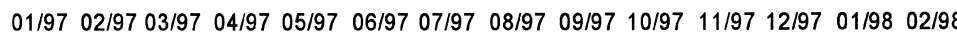

Fig. 3. Seasonal course of 5-day averages of ecosystem respiration at the Puéchabon and Castelporziano sites, derived from eddy covariance measurements, modelled by non-linear regression with model IV, and residual.

The different non-linear regression models of ecosystem respiration performed quite differently (Table 3 ). The widely used model I explains only $70 \%$ of the variance of ecosystem respiration for the Puéchabon siteand 54\% for Castelporziano. More importantly, from the residual plot versus soil moisture (Fig. 4a) it is obvious that the model had a systematic bias, underestimating the flux at medium water contents and overestimating the flux at high and low water contents. Additionally, this model gave unrealistic results at high water contents (Fig. 4b): according to this model there was an increasing flux with increasing moisture, even above field capacity.

In contrast, the modified soil moisture function (model II) did not exhibit these properties (Fig. 4b). The shape of the difference curve is quite similar to the residual curve in Fig. 4. The modified soil moisture function (model II) provides distinctly better fits (Table 4), modelling efficiency and $r^{2}$ ranging between 0.68 and $0 \cdot 83$. Also, model II was unbiased for moisture and temperature (see residual plots, Fig. 5). The residuals were statistically independent from friction velocity $\left(u^{*}\right)$ (Fig. 5), suggesting that the removal of $u^{*}$ below the threshold value was satisfactory. Finally, with the optimized parameters the shape of the curve was more realistic than with model I (Fig. 4b; Table 3): it rapidly approached a maximum and increased little in wet soil. On both sites, the model fit resulted in a parameterization with a high sensitivity of ecosystem respiration to soil moisture. The half-maximal water content $\left(\theta_{1 / 2}\right)$ was less than $3 \%$ above the residual water content.

Although model II satisfactorily described the response to drought without bias, one assumption can be questioned from the results of model III and IV: the assumption that temperature sensitivity $\left(Q_{10}\right)$ is independent of soil moisture. In model III the data were classified into moisture classes, and $Q_{10}$ functions fitted to the data (Fig. 6). Respiration at a reference temperature of $15{ }^{\circ} \mathrm{C}$ increased with increasing moisture

Table 3. Non-linear regression results of ecosystem respiration versus soil temperature and soil water content with models I and II. Approimate standard errors of the parameter estimates are shown in parentheses. Reference temperature for $R_{\text {eco }}$ is $15^{\circ} \mathrm{C}$

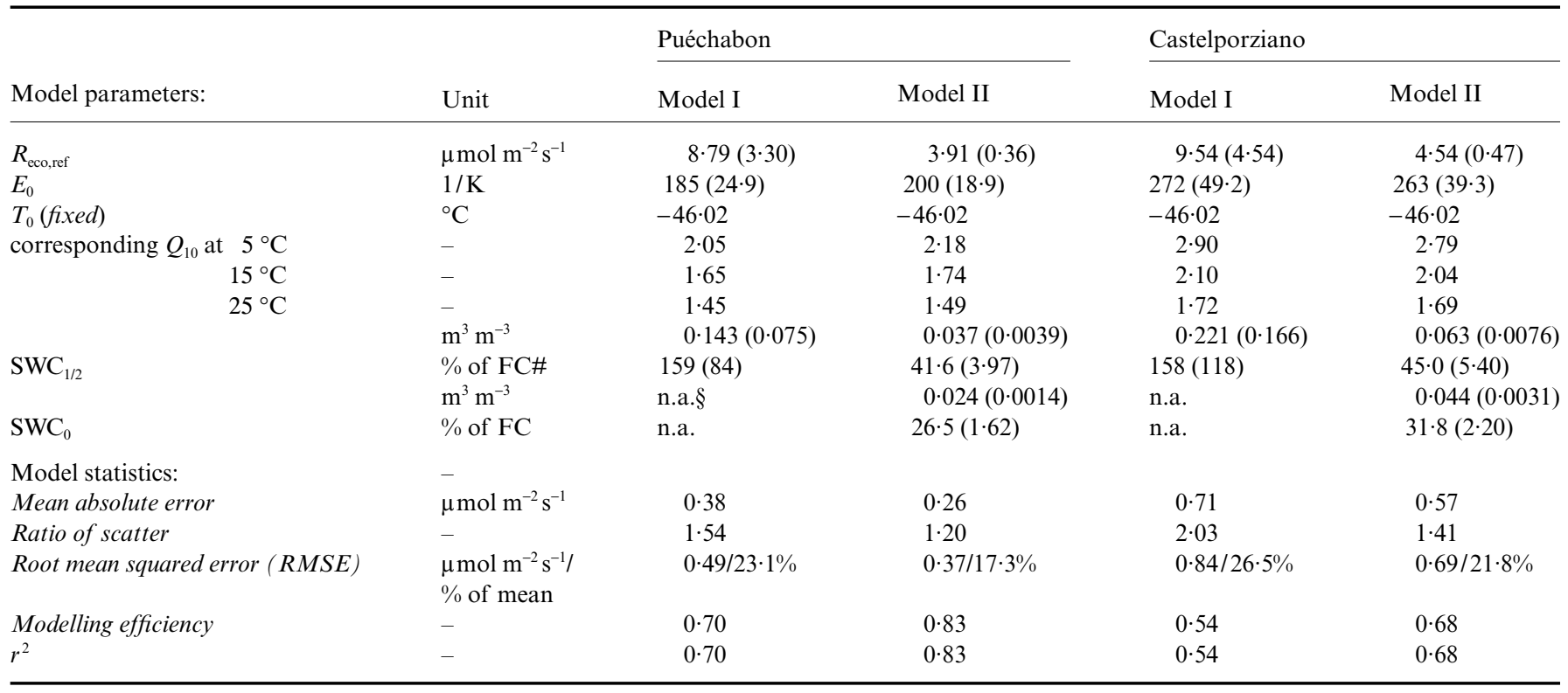

\#: FC = field capacity; §: n.a. = not applicable. 

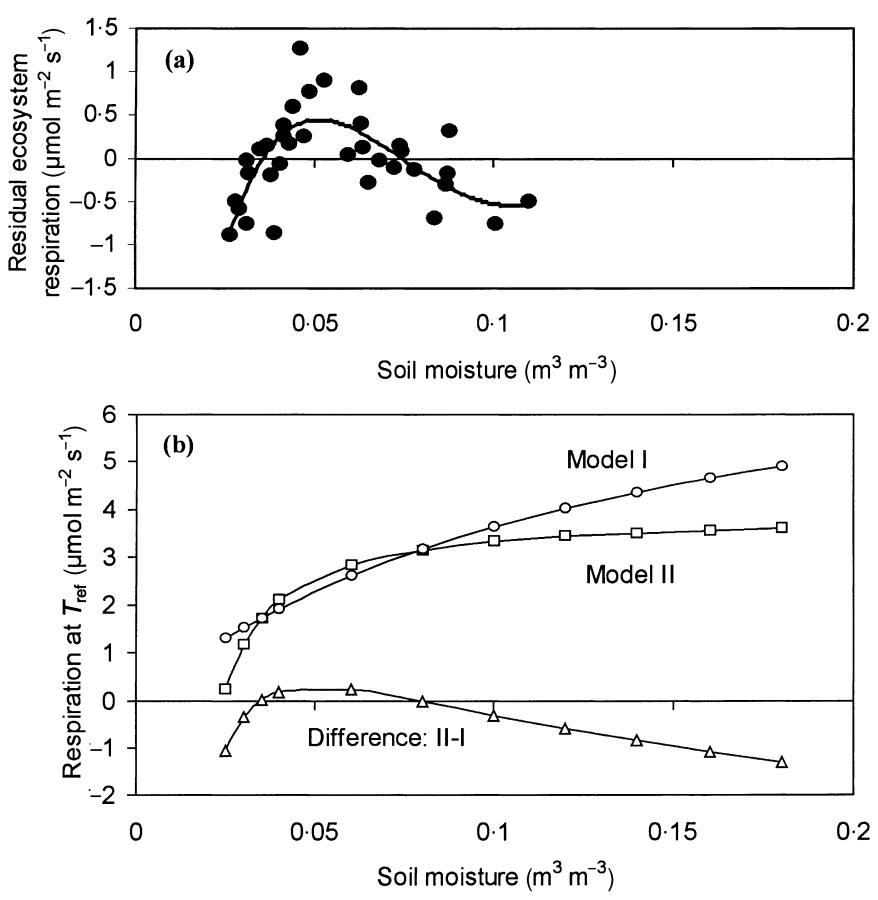

Fig. 4. (a) Residual plot of ecosystem respiration from model I versus soil moisture for the Puéchabon site, showing the model bias. The polynomial relationship of third degree is significant ( $F$ test, $P<0 \cdot 05$ ). (b) Comparison between ecosystem respiration as predicted by models I model II for the Puéchabon site.

(Fig. 7). In addition, the $Q_{10}$ of respiration at both sites increased monotonically from about $1 \cdot 0$ (no response) in dry soil to above 2.0 at field capacity (Fig. 7). When data from the two sites were pooled, the trend of increasing $Q_{10}$ with soil water content was highly significant $(P<0 \cdot 01 ; N=7$; Spearman's rank correlation). A moisture-dependent $Q_{10}$ was also found when the $Q_{10}$ was expressed as a linear function of soil moisture (model IV, eqn 6): At both sites the slope was pos- itive, and for Puéchabon the $Q_{10}$ of respiration increased by 0.96 if soil water content increased by $0.1 \mathrm{~m}^{3} \mathrm{~m}^{-3}$ (Table 4). However, in this multiple non-linear regression the standard errors were relatively large. Although the fit of model IV was good (Fig. 8a), the time-course of the residuals varied seasonally (Fig. 3), for example, at the Puéchabon site a trend in the residuals was perceptible from August to October.

\section{MODELLED SOIL MICROBIAL RESPIRATION}

The estimated soil microbial respiration with ICBM averaged $1.0 \mu \mathrm{mol} \mathrm{m}^{-2} \mathrm{~s}^{-1}$ or about $50 \%$ of the estimated ecosystem respiration in the period. The relative proportion of soil microbial respiration to ecosystem respiration did not change substantially over time, despite the non-uniform litter input. According to the ICBM, the labile $\mathrm{C}$ pool changed by a maximum of $4.4 \mathrm{~mol} \mathrm{~m}^{-2}(7 \%)$ and normalized soil microbial respiration changed by an even smaller percentage (Fig. 9). The most rapid change of approximately $-2 \%$ per month occurred in September and October.

\section{Discussion}

The normalized ecosystem respiration rates of the two sites $\left(R_{\text {eco,ref }}\right)$ differed between the sites by a factor of $1 \cdot 16$, nearly the same factor as the leaf area index (LAI; 1-21). This result is expected, as leaves themselves respire, and supporting respiring tissue (stems, roots) and litter input to the soil generally increase with LAI. If species composition and other conditions do not change, LAI should be a good predictor of normalized ecosystem respiration. If this hypothesis remains valid, it could profitably be used in combination with remotely sensed vegetation indices.

Table 4. Non-linear regression results of ecosystem respiration versus soil temperature and soil water content with models III and IV. Approimate standard errors of the parameter estimates are shown in parentheses. Reference temperature for $R_{\text {eco }}$ is $15^{\circ} \mathrm{C}$

\begin{tabular}{|c|c|c|c|c|c|c|c|c|c|c|}
\hline \multirow[b]{3}{*}{ Parameter: } & \multirow[b]{3}{*}{ Unit } & \multicolumn{5}{|c|}{ Puéchabon } & \multicolumn{4}{|c|}{ Castelporziano } \\
\hline & & \multicolumn{4}{|c|}{ Model III at moisture Vol- $\%$ : } & \multirow[t]{2}{*}{ Model IV } & \multicolumn{3}{|c|}{ Model III at moisture Vol-\%: } & \multirow[t]{2}{*}{ Model IV } \\
\hline & & $3 \cdot 12$ & $4 \cdot 1$ & $6 \cdot 3$ & $8 \cdot 6$ & & $6 \cdot 59$ & $13 \cdot 0$ & $15 \cdot 9$ & \\
\hline$R_{\text {eco,ref }}$ & $\mu \mathrm{mol} \mathrm{m}{ }^{-2} \mathrm{~s}^{-1}$ & $\begin{array}{l}1 \cdot 47 \\
(0 \cdot 17)\end{array}$ & $\begin{array}{l}2 \cdot 11 \\
(0 \cdot 24)\end{array}$ & $\begin{array}{l}2 \cdot 83 \\
(0 \cdot 14)\end{array}$ & $\begin{array}{l}3 \cdot 01 \\
(0 \cdot 11)\end{array}$ & $\begin{array}{l}3 \cdot 81 \\
(0 \cdot 37)\end{array}$ & $\begin{array}{l}2 \cdot 98 \\
(0 \cdot 69)\end{array}$ & $\begin{array}{l}3 \cdot 74 \\
(0 \cdot 29)\end{array}$ & $\begin{array}{l}3 \cdot 72 \\
(0 \cdot 33)\end{array}$ & $\begin{array}{l}4 \cdot 28 \\
(0 \cdot 51)\end{array}$ \\
\hline$Q_{10}$ & - & $\begin{array}{l}1 \cdot 26 \\
(0 \cdot 18)\end{array}$ & $\begin{array}{l}1 \cdot 34 \\
(0 \cdot 32)\end{array}$ & $\begin{array}{l}1.65 \\
(0 \cdot 14)\end{array}$ & $\begin{array}{l}1.98 \\
(0 \cdot 13)\end{array}$ & $\begin{array}{l}=1,14(0 \cdot 26) \\
+9 \cdot 60(4 \cdot 28) \cdot \theta \$\end{array}$ & $\begin{array}{l}0.93 \\
(0 \cdot 37)\end{array}$ & $\begin{array}{l}1 \cdot 70 \\
(0 \cdot 31)\end{array}$ & $\begin{array}{l}2 \cdot 32 \\
(0 \cdot 39)\end{array}$ & $\begin{array}{l}=1 \cdot 17(1.06) \\
+5.95(7.22) \cdot \theta \$\end{array}$ \\
\hline $\mathrm{SWC}_{1 / 2}$ & $\begin{array}{l}\mathrm{m}^{3} \mathrm{~m}^{-3} \\
\% \text { of } \mathrm{FC} \#\end{array}$ & n.a. $\S$ & n.a. & n.a. & n.a. & $\begin{array}{l}0 \cdot 037(0 \cdot 0037) \\
40 \cdot 7(4 \cdot 2)\end{array}$ & n.a. & n.a. & n.a. & $\begin{array}{l}0.057(0.011) \\
40 \cdot 8(11 \cdot 9)\end{array}$ \\
\hline $\mathrm{SWC}_{0}$ & $\begin{array}{l}\mathrm{m}^{3} \mathrm{~m}^{-3} \\
\% \text { of } \mathrm{FC}\end{array}$ & n.a. & n.a. & n.a. & n.a. & $\begin{array}{l}0 \cdot 023(0 \cdot 0021) \\
25 \cdot 6(2 \cdot 34)\end{array}$ & n.a. & n.a. & n.a. & $\begin{array}{l}0 \cdot 045(0 \cdot 0034) \\
31 \cdot 9(3 \cdot 73)\end{array}$ \\
\hline Statistics: & & & & & & & & & & \\
\hline $\begin{array}{l}M A E \\
R M S E\end{array}$ & $\begin{array}{l}\mu \mathrm{mol} \mathrm{m} \mathrm{m}^{-2} \mathrm{~s}^{-1} \\
\mu \mathrm{mol} \mathrm{m} \mathrm{m}^{-2} \mathrm{~s}^{-1}\end{array}$ & $\begin{array}{l}0 \cdot 32 \\
0 \cdot 41\end{array}$ & $\begin{array}{l}0 \cdot 48 \\
0 \cdot 62\end{array}$ & $\begin{array}{l}0 \cdot 30 \\
0 \cdot 35\end{array}$ & $\begin{array}{l}0 \cdot 21 \\
0 \cdot 25\end{array}$ & $\begin{array}{l}0 \cdot 26 \\
0 \cdot 37\end{array}$ & $\begin{array}{l}0 \cdot 93 \\
1 \cdot 10\end{array}$ & $\begin{array}{l}0.58 \\
0.69\end{array}$ & $\begin{array}{l}0 \cdot 65 \\
0 \cdot 74\end{array}$ & $\begin{array}{l}0 \cdot 56 \\
0.68\end{array}$ \\
\hline$M E F$ & - & $0 \cdot 29$ & $0 \cdot 19$ & $0 \cdot 86$ & 0.94 & $0 \cdot 83$ & $0 \cdot 01$ & $0 \cdot 58$ & $0 \cdot 72$ & $0 \cdot 69$ \\
\hline$r^{2}$ & - & $0 \cdot 29$ & $0 \cdot 19$ & $0 \cdot 86$ & $0 \cdot 94$ & $0 \cdot 83$ & $0 \cdot 01$ & $0 \cdot 58$ & $0 \cdot 72$ & $0 \cdot 69$ \\
\hline
\end{tabular}

$\$: \theta=$ soil water content $\left(\mathrm{m}^{3} \mathrm{~m}^{-3}\right) ; \#: \mathrm{FC}=$ field capacity; $\$$ : n.a. = not applicable. 

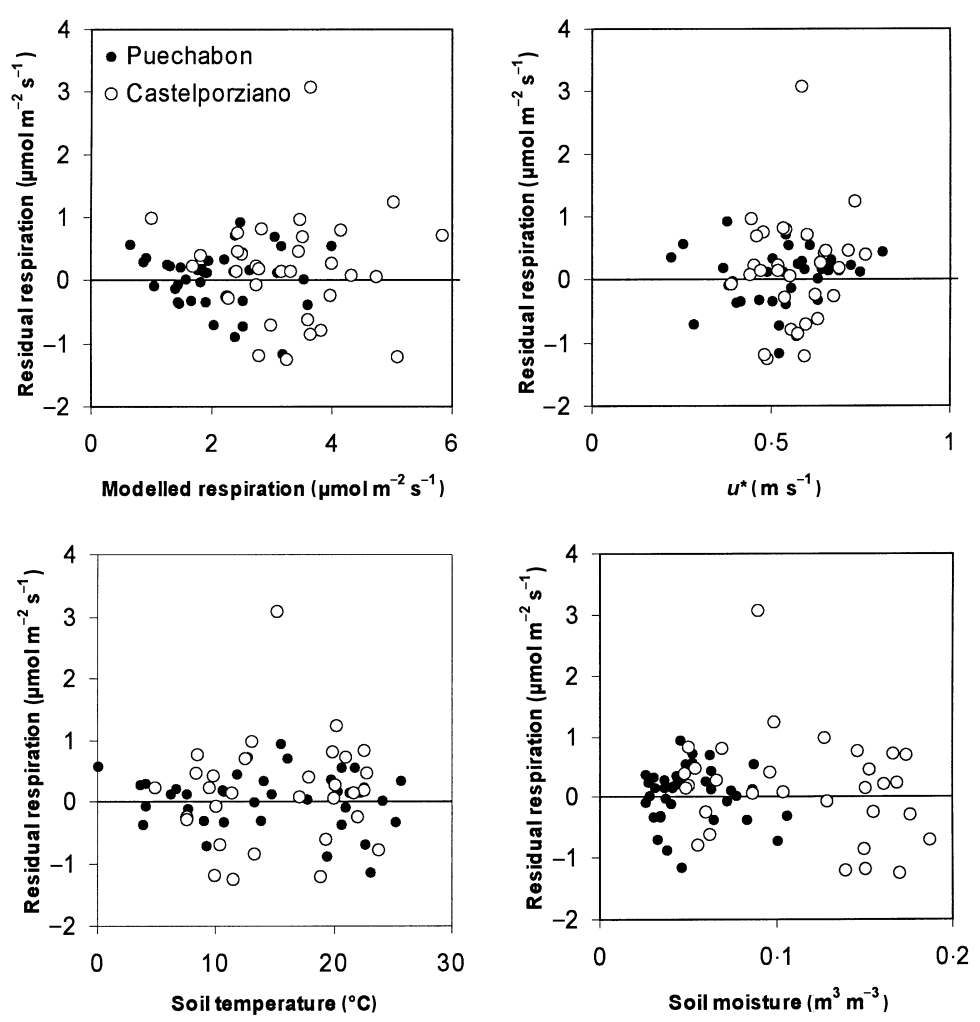

Fig. 5. Residual plots for the non-linear regression of ecosystem respiration dependent on soil moisture and temperature (model II). For both sites, and in all plots, polynomial trends up to the third degree were not significant $(F$ test, $P>0 \cdot 05$ ).

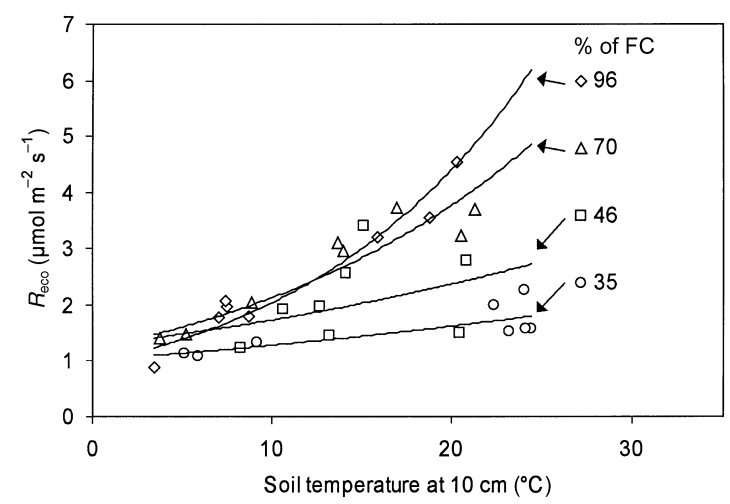

Fig. 6. The relationship between ecosystem respiration $\left(R_{\text {eco }}\right)$ and soil temperature within four different soil moisture classes at the Puéchabon site. The solid lines represent exponential $\left(Q_{10}\right)$ fits for each soil moisture class. For each moisture class, the average soil moisture in percentage of field capacity is indicated beside the symbol.

At both sites ecosystem respiration exhibited a clear seasonality, with maxima occurring in spring and autumn. A clear drop in ecosystem respiration occurs during the drought, and the autumn peak coincided with the first rain event. Consequently, a large proportion of the variance can be explained by a non-linear regression on soil temperature and moisture. The estimated temperature dependence of ecosystem respiration

(C) 2002 British Ecological Society, Functional Ecology, 16, 27-39 (expressed as $Q_{10}$ at $15^{\circ} \mathrm{C}$ ) is weaker than previously found for soil C mineralization (Leirós et al. 1999), but slightly higher than for leaf respiration (Tenhunen et al. 1987) in Mediterranean-type ecosystems.
The residual analysis shows no bias of the temperature function provided by Lloyd \& Taylor (1994). However, the often-used simple Michaelis-Mententype function for the dependence of respiration on soil moisture (e.g. Carlyle \& BaThan 1988; Hanson et al. 1993) was inadequate to describe the dynamics. It introduces a bias because its sensitivity to soil moisture in dry soil is too low. Thus a modification of this model function is proposed, introducing a residual water content at which respiration ceases (eqn 5). This is consistent with parameterizations based on soil physical retention curves, where the soil water potential is highly sensitive to moisture content in drier soil (Marshall \& Holmes 1988) and where a residual water content is often introduced at which water potential converges toward infinity (e.g. van Genuchten 1980). In addition, and in contrast to the 'simple' function, the proposed function (eqn 5) does not predict increasing respiration at water contents above field capacity. The modified function should be preferred for both theoretical and empirical reasons, at least in dry soil.

Inter-site comparisons of parameters such as $\mathrm{SWC}_{1 / 2}$ in this study are difficult, because volumetric soil water content provides no direct indications about water availability. In the highly rocky soil ( $>70 \%$ coarse fraction) at Puéchabon, for example, a water content of $0.06 \mathrm{~m}^{3} \mathrm{~m}^{-3}$ indicates a relatively high water availability, while the same volume fraction at Castelporziano represents relatively low water availability. As a surrogate for water availability, the water content can be expressed as a percentage of field capacity, here defined as water content at a matric potential of $330 \mathrm{hPa}$. Then the $\mathrm{RSWC}_{1 / 2}$ values are quite similar, around $40 \%$ of field capacity with overlapping confidence intervals, indicating that relative soil water content is a better measure of soil water availability than absolute volumetric moisture content. It is also possible to use soil water potential as the independent variable in the moisture function, but water potential is not as conveniently measured as volumetric moisture by means of TDR or neutron probe, particularly under very dry conditions.

An assumption made in most soil respiration models is that respiration can be described by a simple multiplicative effect of temperature and moisture. This was challenged for ecosystem respiration by two different data analyses. The temperature sensitivity of respiration was not independent of moisture, but the $Q_{10}$ increased from about 1.0 to $>2.0$ with increasing moisture, suggesting a model with an increasing $Q_{10}$ for increasing soil moisture (eqn 6). It might be argued that the predictive power of this model IV was similar to model II (only slightly higher $r^{2}$ ), but the relatively good performance of model II results from its 'effective' parameterization via the regression analysis and does not necessarily mean that it is correct. A $Q_{10}$ varying between 0.8 and 2.6 with soil moisture was reported by Carlyle \& BaThan (1988). Recently, Borken et al. (1999) also found a flatter response 
35

Analysis of

ecosystem

respiration
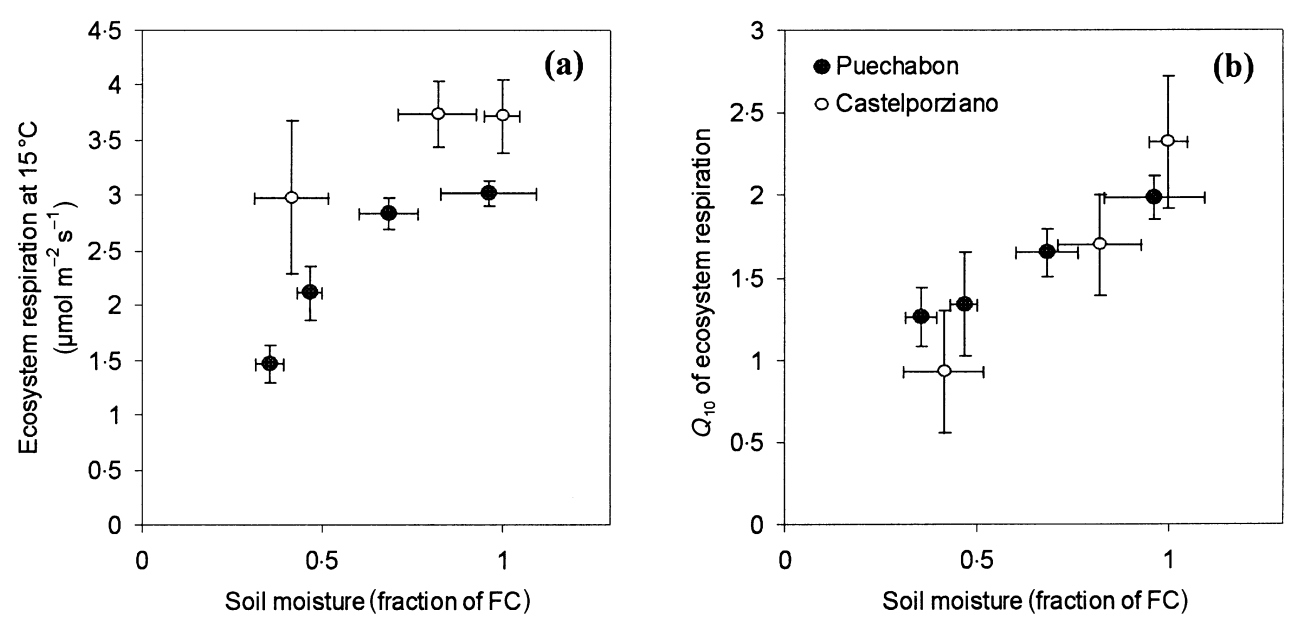

Fig. 7. Results from model III: relationship between (a) ecosystem respiration at $T_{\text {ref }}=15^{\circ} \mathrm{C}$ and soil moisture, and between (b) estimated $Q_{10}$ of ecosystem respiration and soil moisture for the Puéchabon and Castelporziano sites. Horizontal error bars represent standard deviation of soil moisture within moisture classes; vertical bars indicate standard errors of estimate for the parameters.

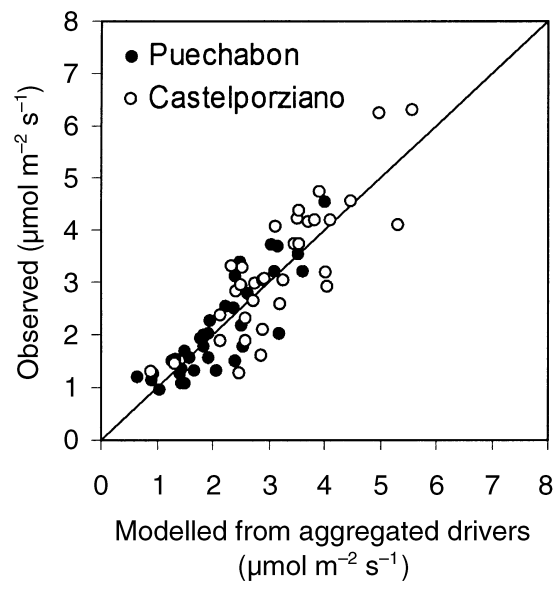

Fig. 8. Scatter plots of observed 5-day mean ecosystem respiration versus regression model IV with 5-day mean drivers. curve of soil respiration to temperature in an experimental drought plot compared to a well watered plot.

Several mechanisms may account for an apparently variable $Q_{10}$ of soil and ecosystem respiration.

(i) There is evidence that $Q_{10}$ of decomposition is higher for labile than for stable substrates (Anderson 1991; Liski et al. 1999). Labile substrates are often associated with coarse fractions (litter), and these dry out first, so that they do not respire under dry conditions. Consequently, the $Q_{10}$ drops, because under dry conditions most respiration comes from more stable material, which only allows a lower $Q_{10}$.

(ii) A similar effect would occur with partial inactivation of the rhizosphere during soil drying, as a higher $Q_{10}$ was found in the rhizosphere than the bulk soil (Boone et al. 1998).

(iii) In the dry period, $\mathrm{C}$ assimilation of the canopy was severely reduced, so that fewer assimilates are
(C) 2002 British Ecological Society, Functional Ecology, 16, 27-39

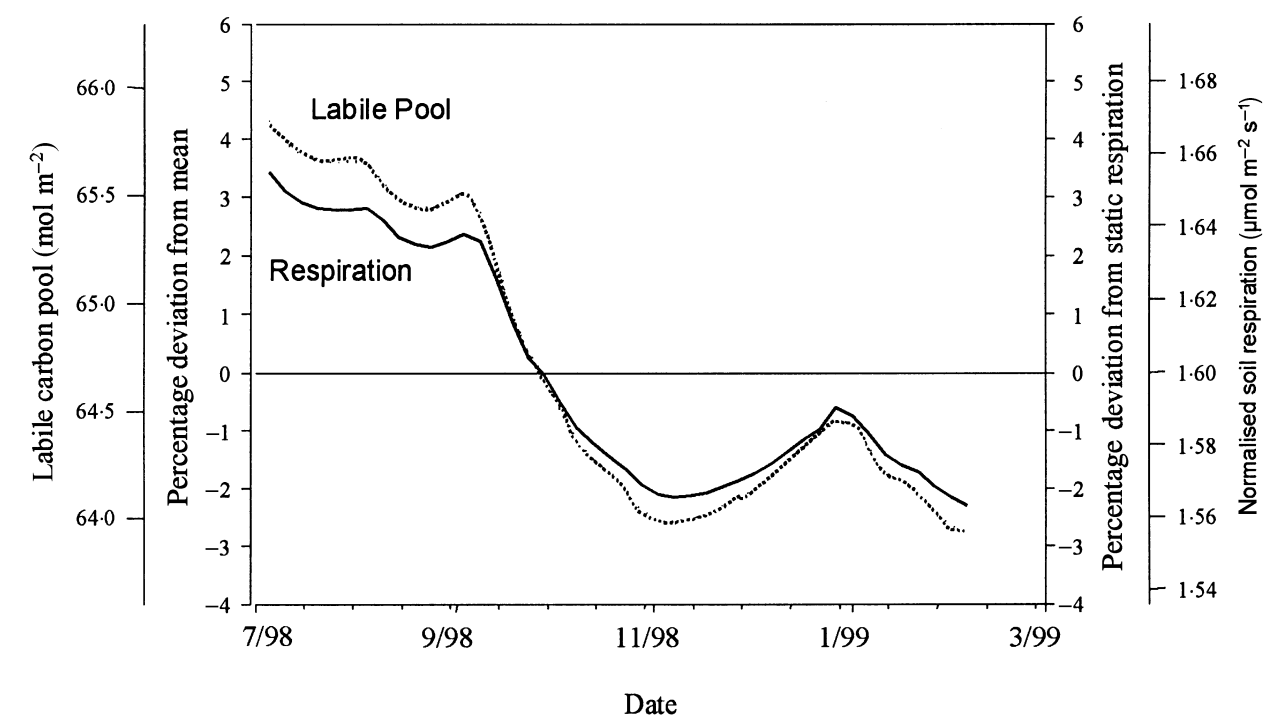

Fig. 9. Development of labile pool size and soil microbial respiration (standardized to $10{ }^{\circ} \mathrm{C}$ and to half-maximal moisture), expressed in relative (inner axes) and absolute (outer axes) units for the Puéchabon site. Static respiration means respiration when the labile pool is assumed to be constant, as in the regression model. 
M. Reichstein et al. expected to be transported towards the rhizosphere (source limitation of rhizosphere respiration) leading to the same effect as in (ii).

Because whole-ecosystem respiration was studied here, we emphasize the importance of effects such as varying $Q_{10}$ at the ecosystem level. We need more information on how temperature and drought affect respiration. These results have implications for future climate-change scenarios (e.g. Cox et al. 2000). They stress the importance of changes in soil moisture in two ways: not only is the direct sensitivity of ecosystem respiration to soil moisture in a dry soil important, but also the indirect moisture effect on the temperature dependence would reduce the respiration-enhancing effect of higher temperatures. The results of Lloyd $\&$ Taylor (1994), indicating a decreasing $Q_{10}$ of soil respiration with increasing temperature, may result from the correlation between drier and warmer soil temperatures. In support of this idea, Kätterer et al. (1998) found no such temperature effect on the $Q_{10}$ from a compilation of laboratory studies which were performed at optimal moisture. This calls for testing of other data sets to determine whether this pattern is general.

With the regression model IV (eqns 5 and 6), more than two-thirds of the variation in measured ecosystem respiration was explained at both sites. The variation not explained by the models may be associated with several errors. At least four factors might have contributed to this partial disagreement.

(i) There is still some random error in the eddy covariance data, despite aggregation into 5-day periods. Particularly when the data were fluctuated around the relatively stable model values (e.g. February to April in Castelporziano, or December in Puéchabon), this error seems probable, although no systematic dependency on friction velocity $\left(u^{*}\right)$ has been found. For instance, varying source areas of the $\mathrm{CO}_{2}$ fluxes ('footprint') might have contributed to the variation in estimated ecosystem respiration.

(ii) The data were pooled into 5-day intervals in order to obtain a relatively large number of data points, which reduces the random error inherent to the eddy covariance measurements by the factor $\sqrt{\text { sample }}$ size (Moncrieff et al. 1996; Sachs 1996). While reducing the random error of the measurements, naturally occuring variability is also 'smoothed' out. As respiration depends non-linearly on soil moisture and temperature, aggregation errors must be expected (Lischke et al. 1997; Rastetter et al. 1992). This error was estimated by applying the fitted respiration model function to the hourly values of temperature and moisture from the soil model and averaging the function over the same period that was used for averaging the driving variables. For both sites, the aggregation error for respiration was less than a $2 \%$ overestimate (Reichstein 2001).

(iii) A third source of error is that the predictor variables themselves are a model output, although the agreement between modelled and measured soil conditions was good.

(iv) Most importantly, the large ecosystem respiration in May/June for Castelporziano, and the underestimation of respiration by the best abiotic model IV in October on the Puéchabon site, indicate that seasonality of biotic processes influences the annual course of ecosystem respiration.

Several biotic factors might contribute to seasonal variability in respiration: phenologically controlled respiration of leaves, roots and rhizosphere (Lavigne et al. 1997; Ryan et al. 1997); death and regrowth of microbes within drying-rewetting cycles (Orchard \& Cook 1983; Pulleman \& Tietema 1999); macrofaunal activity (Coleman 1996); and variability in litter fall and root death and, thus, changes in available $\mathrm{C}$ pools for decomposition. While (in contrast to deciduous forests) intra-annual changes in LAI are minor at our two evergreen forest sites, growth respiration of fine roots and new leaves may still have contributed to the large ecosystem respiration in May at Castelporziano.

The importance of seasonal variability of soil $\mathrm{C}$ pool size appeared to be minor in this study. By applying a dynamic soil organic matter decomposition submodel, the labile pool size varied by $7 \%$ maximally, despite sixfold month-to-month changes in litter input. The relatively small inputs cannot significantly influence the overall litter pool for decomposition throughout the season (monthly input is maximally $23 \%$ of the litter pool). With changes in pool sizes of $7 \%$, changes in normalized soil microbial respiration were only $5 \%$ or $0 \cdot 1 \mu \mathrm{mol} \mathrm{m} \mathrm{m}^{-1}$, which is small compared to the residuals of the regression model.

Two $\mathrm{C}$ pools may be too few to describe intraannual dynamics, and rapid decomposition of labile substances could contribute significantly to seasonal variability (e.g. sugars and amino-acids; Kuzyakov \& Demin 1998). However, a simple calculation suggests that this is improbable. If we conservatively assume that all the soluble sugar in litter input is decomposed within 1 day, the maximal flux from this compartment would be $6 \mathrm{~g}$ litter $\mathrm{m}^{-2}$ day $^{-1} \times 0.5 \times 10^{-3} \mathrm{~g}$ sugar $(\mathrm{g} \text { litter })^{-1}=3 \cdot 0 \times 10^{-3} \mathrm{~g}$ sugar $\mathrm{m}^{-2}$ day $^{-1}=1 \cdot 2 \times 10^{-3} \mathrm{~g}$ sugar $\mathrm{C} \mathrm{m}^{-2}$ day $^{-1}=1 \cdot 14 \times 10^{-3} \mu \mathrm{mol} \mathrm{C} \mathrm{m}^{-2} \mathrm{~s}^{-1}$, which is negligible. In this calculation, a sugar content in the litter of $500 \mathrm{mg} \mathrm{kg}^{-1}$ was assumed for $Q$. ilex aboveground litter (Gillon et al. 1994). Indirect effects of fresh litter ('priming' effect: Anderson \& Domsch 1986; Högberg \& Ekblad 1996) have not been considered.

It is possible that soil microbial growth dynamics add to the seasonal variability of ecosystem respiration. Merzouki (1986) found an increase in soil microbial biomass $\mathrm{C}$ from $2 \cdot 0$ to $3 \cdot 2 \%$ of organic $\mathrm{C}$ within 2 months (September-November), which corresponds to a flux of $1.2 \% \times 3.25 \mathrm{~kg} \mathrm{C} \mathrm{m}^{-2} / 2$ months $=0.63$ $\mu \mathrm{mol} \mathrm{C} \mathrm{m} \mathrm{C} \mathrm{s}^{-1}$. If we further assume microbial C-use efficiency of $0 \cdot 28$, then this results in a respiratory flux due to microbial growth of $0.63 \times(1 / 0.28-1)=1.62$
Functional Ecology, 16, 27-39 
37

Analysis of ecosystem respiration

$\mu \mathrm{mol} \mathrm{m} \mathrm{m}^{-2} \mathrm{~s}^{-1}$ (cf. Ågren \& Bosatta 1996). This exceeds even the residual of the regression model in these months (Fig. 3). We conclude that microbial growth respiration might contribute more significantly to the seasonality of ecosystem respiration in an evergreen forest than do changing litter pools, and the actual effect should be more thoroughly studied in combination with root growth (Merzouki 1986; Ryan et al. 1997). The dynamics of litter pools have more influence on the interannual variability of $\mathrm{C}$ fluxes, because the time during which litter pools potentially build up or disappear is longer.

A second reason for applying the soil $\mathrm{C}$ balance model (ICBM) was to estimate soil microbial respiration at Puéchabon to make an initial separation from the top-down estimate of ecosystem respiration. The results indicate that microbial respiration was the largest contribution to ecosystem respiration (50\%). If we assume that above- and below-ground autotrophic respiration is roughly equal, then root respiration would be $25 \%$ of total ecosystem respiration, or one-third of soil plus litter respiration. This agrees with experimental studies in forest and heath ecosystems (Bowden et al. 1993; Chapman 1979), but is clearly at the lower end of the $30-70 \%$ reported by Raich \& Schlesinger (1992) in a global survey. The estimate of soil microbial respiration contributing approximately $50 \%$ to ecosystem respiration depends on the reliability of the eddy covariance data and the independent parameterization of the ICBM. If ecosystem respiration was underestimated by the eddy covariance technique by $27 \%$, as in Lavigne et al. (1997), soil microbial respiration would still be $40 \%$ of total ecosystem respiration, and root respiration would be $42 \%$ of total soil respiration, with the same assumption about autotrophic respiration partitioning as above. Another interesting hypothesis from the data-model comparison is that not only decomposition, but also autotrophic respiration, is strongly affected by the drought. For the Puéchabon site, only $0.5 \mu \mathrm{mol} \mathrm{m}{ }^{-2} \mathrm{~s}^{-1}$ respiration (= observed ecosystem respiration minus modelled decomposition respiration at the end of the drought) would be left for plant respiration at $25-30{ }^{\circ} \mathrm{C}$ air temperature. This would mean a considerable reduction in leaf respiration through drought, which is not yet included in models (cf. Baldocchi 1997; Tenhunen et al. 1994; Williams et al. 1996). This hypothesis is supported by some data (Pereira et al. 1986; Tretiach et al. 1997). Tretiach et al. (1997) studied Q. ilex leaves and found small differences in leaf respiration rate between August and October, although air temperature differed by more than $10^{\circ} \mathrm{C}$.

\section{Conclusions}

(C) 2002 British

Ecological Society, Functional Ecology, 16, 27-39 (i) A drought- and temperature-dependent intra-annual time-course of ecosystem respiration was derived from eddy covariance data for two Mediterranean evergreen oak forest sites. (ii) The Lloyd \& Taylor (1994) model for temperature dependence of soil respiration performed well.

(iii) However, a new functional dependence of ecosystem respiration on soil moisture is suggested, with a higher sensitivity at low water contents than in current models.

(iv) In addition, the data reveal that the temperature sensitivity $\left(Q_{10}\right)$ of ecosystem respiration increases with soil moisture, so that the validity of commonly used multiplicative models is questioned.

(v) As a conclusion from the application of a $\mathrm{C}$ balance model, the intra-annual dynamic of litter pools is likely to have little influence on the seasonality of ecosystem respiration, but microbial growth dynamics might have a larger influence. If these patterns are confirmed at other sites, the modified relationships (points iii and iv) should be included in future C-cycle and climate-change models.

\section{References}

Ågren, G.I. \& Bosatta, E. (1996) Theoretical Ecosystem Ecology - Understanding Nutrient Cycles. Cambridge University Press, Cambridge, UK.

Anderson, J.M. (1991) The effects of climate change on decomposition processes in grassland and coniferous forests. Ecological Applications 1, 326-347.

Anderson, T.-H. \& Domsch, K.H. (1986) Carbon link between microbial biomass and soil organic matter. Perspectives in Microbial Ecology (eds F. Megusár \& M. Gantar), pp. 467471. Slovene Society for Microbiology, Ljubljana.

Andrén, O. \& Kätterer, T. (1997) ICBM - the introductory carbon balance model for exploration of soil carbon balances. Ecological Applications 7, 1226-1236.

Aubinet, M., Grelle, A., Ibrom, A. et al. (2000) Estimates of the annual net carbon and water exchange of forests: The EUROFLUX methodology. Advances in Ecological Research 30, 113-175.

Baldocchi, D.D. (1997) Measuring and modelling carbon dioxide and water vapour exchange over a temperate broadleaved forest during the 1995 summer drought. Plant, Cell and Environment 20, 1108-1122.

Baldocchi, D.D., Valentini, R., Running, S., Oechel, W. \& Dahlman, R. (1996) Strategies for measuring and modelling carbon dioxide and water vapour fluxes over terrestrial ecosystems. Global Change Biology 2, 159-168.

Boone, R.D., Nadelhoffer, K., Canary, J.D. \& Kaye, J.P. (1998) Roots exert a strong influence on the temperature sensitivity of soil respiration. Nature 396, 570-572.

Borken, W., Xu, Y.J., Brumme, R. \& Lamersdorf, N. (1999) A climate change scenario for carbon dioxide and dissolved organic carbon fluxes from a temperate forest soil: drought and rewetting effects. Soil Science Society of America Journal 63, 1848-1855.

Bottner, P., Coûteaux, M.M. \& Vallejo, V.R. (1995) Soil organic matter in mediterranean-type ecosystems and global climatic changes: a case study - the soil of the Mediterranean Basin. Global Change and Mediterranean-Type Ecosystems (eds J. M. Moreno \& W. C. Oechel), pp. $306-$ 325. Springer, Berlin.

Bowden, R.D., Nadelhoffer, K.J., Boone, R.D., Melillo, J.M. \& Garrison, J.B. (1993) Contributions of aboveground litter, belowground litler, and root respiration to total soil respiration in a temperate mixed hardwood forest. Canadian Journal of Forest Research 23, 1402-1407.

Bunnell, F.L., Tait, D.E.N., Flanagan, P.W. \& van Cleve, K. (1977) Microbial respiration and substrate weight loss - I. 
M. Reichstein et al.
A general model of the influences of abiotic variables. Soil Biology and Biochemistry 9, 33-40.

Carlyle, J.C. \& BaThan, U. (1988) Abiotic controls of soil respiration beneath an 18-year-old Pinus radiata stand in South-East Australia. Journal of Ecology 76, 654-662.

Casals, P., Romanya, J., Cortina, J., Bottner, P., Couteaux, M.M. \& Vallejo, V.R. (2000) $\mathrm{CO}_{2}$ efflux from a Mediterranean semi-arid forest soil. I. Seasonality and effects of stoniness. Biogeochemistry 48, 261-281.

di Castri, F. (1981) Mediterrnean-type shrublands of the world. Mediterranean-type Shrublands (F. Di Castri, D. W. Goodall \& R. L. Specht), pp. 1-52. Elsevier, Amsterdam.

Chapman, S.B. (1979) Some interrelationships between soil and root respiration in lowland Calluna heathland in southern England. Journal of Ecology 67, 1-20.

Coleman, D.C. (1996) Fundamentals of Soil Ecology. Academic Press, San Diego.

Cox, P.M., Betts, R.A., Jones, C.D., Spall, S.A. \& Totterdell, I.J. (2000) Acceleration of global warming due to carboncycle feedbacks in a coupled climate model. Nature 408, 184-187.

Davidson, E.A., Belk, E. \& Boone, R.D. (1998) Soil water content and temperature as independent or confounded factors controlling soil respiration in temperate mixed hardwood forest. Global Change Biology 4, 217-227.

Deutschmann, G., Malessa, V. \& Rummenhohl, H. (1994) Bestimmung der Lagerungsdichte in stark skeletthaltigen Böden. Zeitschrift für Pflanzenernährung und Bodenkunde 157, 77-79.

Draper, N. \& Smith, H. (1981) Applied Regression Analysis. Wiley, New York.

Efron, B. \& Tibshirani, R.J. (1993) An Introduction to the Bootstrap. Chapman \& Hall, New York, NY.

Epron, D., Farque, L., Lucot, E. \& Badot, P.-M. (1999) Soil $\mathrm{CO}_{2}$ efflux in a beech forest: dependence on soil temperature and soil water content. Annals of Forest Science 56, 221-226.

Fang, C. \& Moncrieff, J.B. (1999) A model for soil $\mathrm{CO}_{2}$ production and transport 1: model development. Agricultural and Forest Meteorology 95, 225-236.

van Genuchten, M.T. (1980) A closed-form equation for predicting the hydraulic conductivity of unsaturated soils. Soil Science Society of America Journal 44, 892-898.

Gillon, D., Joffre, R. \& Ibrahima, A. (1994) Initial litter properties and decay rate: a microcosm experiment on Mediterranean species. Canadian Journal of Botany $\mathbf{7 2}$, 946-954

Hanson, P.J., Wullschleger, S.D., Bohlmann, S.A. \& Todd, D.E. (1993) Seasonal and topographic patterns of forest floor $\mathrm{CO}_{2}$ efflux from an upland oak forest. Tree Physiology $\mathbf{1 3}$ $1-15$.

Högberg, P. \& Ekblad, A. (1996) Substrate-induced respiration measured in situ in a $\mathrm{C}_{3}$-plant ecosystem using additions of $\mathrm{C}_{4}$-sucrose. Soil Biology and Biochemistry 28, 1131-1138.

Janssen, P.H.M. \& Heuberger, P.S.C. (1995) Calibration of process oriented models. Ecological Modelling 83, 5566.

Joffre, R., Rambal, S. \& Romane, F. (1996) Local variations of ecosystem functions in Mediterranean evergreen oak woodland. Annales des Sciences Forestales 53, 561570 .

Johnson, L.C., Shaver, G.R., Giblin, A.E. et al. (1996) Effects of drainage and temperature on carbon balance of tussock tundra microcosms. Oecologia 108, 737-748.

Jones, M.H., Fahnestock, J.T., Stahl, P.D. \& Welker, J.M. (2000) A note on summer $\mathrm{CO}_{2}$ flux, soil organic matter, and microbial biomass from different High Arctic ecosystem types in Northwestern Greenland. Arctic, Antarctic and Alpine Research 32, 104-106.

Kätterer, T., Reichstein, M., Andrén, O. \& Lomander, A.
(1998) Temperature dependence of organic matter decomposition: a critical review using literature data analysed with different models. Biology and Fertility of Soils 27, $258-262$.

Keith, H., Jacobsen, K.L. \& Raison, R.J. (1997) Effects of soil phosphorus availability, temperature and moisture on soil respiration in Eucalyptus pauciflora forest. Plant and Soil 190, 127-141.

Kirschbaum, M.U.F. (1995) The temperature dependence of soil organic matter decomposition, and the effect of global warming on soil organic carbon storage. Soil Biology and Biochemistry 27, 753-760.

Kuzyakov, Y. \& Demin, V. (1998) $\mathrm{CO}_{2}$ efflux by rapid decomposition of low molecular organic substances in soils. Sciences of Soils 3, 1-7.

Lavigne, M.B., Ryan, M.G., Anderson, D.E. et al. (1997) Comparing nocturnal eddy covariance measurements to estimates of ecosystem respiration made by scaling chamber measurements. Journal of Geophysical Research 102, 28977-28986.

Leirós, M.C., Trasar-Cepada, C., Seoane, S. \& Gil-Sotres, F. (1999) Dependence of mineralization of soil organic matter on temperature and moisture. Soil Biology and Biochemistry 31, 327-335.

Lischke, H., Loeffler, H.J. \& Fischlin, A. (1997) Calculating temperature dependence over long time periods: a comparison and study of methods. Agricultural and Forest Meteorology 86, 169-181.

Liski, J., Ilvesniemi, H., Mäkelä, A. \& Westman, K.J. (1999) $\mathrm{CO}_{2}$ emissions from soil in response to climatic warming are overestimated - the decomposition of old soil organic matter is tolerant of temperature. Ambio 28, 171-174.

Lloyd, J. \& Taylor, J.A. (1994) On the temperature dependence of soil respiration. Functional Ecology 8, 315-323.

Lossaint, P. \& Rapp, M. (1978) La forêt Méditerranéene de Chênes verts. Structure et Fonctionnement Des Écosystemémes Terrestres (eds M. Lamotte \& F. Bourliére), pp. 129-183. Masson, Paris.

Manes, F., Grignetti, A., Tinelli, A., Lenz, R. \& Ciccioli, P. (1997) General features of the Castelporziano test site. Atmospheric Environment 31, 19-25.

Marshall, T.J. \& Holmes, J.W. (1988) Soil Physics. Cambridge University Press, Cambridge.

Merzouki, A. (1986) Les effets d'une coupe a blanc sur l'activité biologique d'un sol fersiallitique méditerraneén. $\mathrm{PhD}$ Dissertation, CEFE-CNRS, Montpellier.

Moldrup, P., Rolston, D.E. \& Hansen, A.A. (1989) Rapid and numerically stable simulation of one dimensional, transient water flow in unsaturated, layered soils. Soil Science 148, 219-226.

Moldrup, P., Rolston, D.E., Hansen, A.A. \& Yamaguchi, T. (1991) A simple, mechanistic model for soil resistance to plant water uptake. Soil Science 151, 87-93.

Moncrieff, J.B., Malhi, Y. \& Leuning, R. (1996) The propagation of errors in long-term measurements of landatmosphere fluxes of carbon and water. Global Change Biology 2, 231-240.

Norman, J.M., Garcia, R. \& Verma, S.B. (1992) Soil surface $\mathrm{CO}_{2}$ fluxes and the carbon budget of a grassland. Journal of Geophysical Research 97, 18845-18853.

Orchard, V.A. \& Cook, F.J. (1983) Relationship between soil respiration and soil moisture. Soil Biology and Biochemistry 15, 447-454.

Pereira, J.S., Tenhunen, J.D., Lange, O.L., Beyschlag, W., Meyer, A. \& David, M.M. (1986) Seasonal and diurnal patterns in leaf gas exchange of Eucalyptus globulus trees growing in Portugal. Canadian Journal of Forest Research 16, 177-184.

Pinol, J., Alcaniz, J.M. \& Roda, F. (1995) Carbon dioxide efflux and $\mathrm{pCO}_{2}$ in soils of three Quercus ilex montane forests. Biogeochemistry 30, 191-215.
(C) 2002 British

Ecological Society, Functional Ecology, 16, 27-39 
respiration
Pulleman, M. \& Tietema, A. (1999) Microbial C and N transformations during drying and rewetting of coniferous forest floor material. Soil Biology and Biochemistry 31, $275-285$.

Raich, J.W. \& Schlesinger, W.H. (1992) The global carbon dioxide flux in soil respiration and its relationship to vegetation and climate. Tellus 44B, 81-99.

Rastetter, E.B., King, A.W., Cosby, B.J., Hornberger, G.M., O’Neill, R.V. \& Hobbie, J.E. (1992) Aggregating fine scale ecological knowledge to model coarser-scale attributes of ecosystems. Ecological Applications 2, 55-70.

Reichstein, M. (2001) Drought effects on ecosystem gas exchange in three Mediterranean ecosystems. A combined top-down and bottom-up analysis of eddy covariance data. PhD Dissertation, University of Bayreuth.

Reichstein, M., Bednorz, F., Broll, G. \& Kätterer, T. (2000) Temperature dependence of carbon mineralization: conclusions from a long-term incubation of subalpine soil samples. Soil Biology and Biochemistry 32, 947-958.

Rovira, P. \& Vallejo, V.R. (1997) Organic carbon and nitrogen mineralization under Mediterranean climatic conditions: the effects of incubation depth. Soil Biology and Biochemistry 29, 1509-1520.

Ryan, M.G., Lavigne, M.B. \& Gower, S.T. (1997) Annual carbon cost of autotrophic respiration in boreal forest ecosystems in relation to species and climate. Journal of Geophysical Research 102D, 28871-28883.

Sachs, L. (1996) Angewandte Statistik. Anwendung Statistischer Methoden. Springer, Berlin.

Schlentner, R.E. \& van Cleve, K. (1985) Relationship between $\mathrm{CO}_{2}$ evolution from soil, substrate temperature, and substrate moisture in four mature forest types in interior Alaska. Canadian Journal of Forest Research 15, 97 106.

Tenhunen, J.D., Harley, P.C., Beyschlag, W. \& Lange, O.L. (1987) Changes during summer drought in leaf $\mathrm{CO}_{2}$ uptake rates of macchia shrubs growing in Portugal: limitations due to photosynthetic capacity, carboxylation efficiency, and stomatal conductance. Plant Responses to Stress (eds J. D. Tenhunen, F. M. Catarino, O. L. Lange \& W. C. Oechel), pp. 305-327. Springer, Berlin.

Tenhunen, J.D., Siegwolf, R.A. \& Oberbauer, S.F. (1994) Effects of phenology, physiology, and gradients in community composition, structure, and microclimate on tundra ecosystems. Ecophysiology of Photosynthesis, Ecological Studies 100 (eds E. D. Schulze \& M. M. Caldwell), pp. 431-460. Springer, Berlin.

Tretiach, M., Bolognini, G. \& Rondi, A. (1997) Photosynthetic activity of Quercus ilex at the extremes of a transect between Mediterranean and submediterranean vegetation (Trieste-NE Italy). Flora 192, 369-378.

Valentini, R., Scarascia Mugnozza, G. \& Ehleringer, J.R. (1992) Hydrogen and carbon isotope ratios of selected species of a mediterrenean macchia ecosystem. Functional Ecology 6, 627-631.

Valentini, R., Matteucci, G., Dolman, A.J. et al. (2000) Respiration as the main determinant of carbon balance in European forests. Nature 404, 861-865.

Visual Numerics, Inc. (1993) PV-WAVE Advantage. Visual Numerics, Houston, TX.

Vourlitis, G.L. \& Oechel, W.C. (1999) Eddy covariance measurements of $\mathrm{CO}_{2}$ and energy fluxes of an Alaskan tussock tundra ecosystem. Ecology 80, 686-701.

Williams, M., Rastetter, E.B., Fernandes, D.N. et al. (1996) Modelling the soil-plant-atmosphere continuum in a Quercus-Acer stand at Harvard Forest: the regulation of stomatal conductance by light, nitrogen and soil/plant hydraulic properties. Plant, Cell and Environment 19, 911927.

Received 12 March 2001; revised 3 July 2001; accepted 17 July 2001
(C) 2002 British

Ecological Society,

Functional Ecology, 16, 27-39 